\title{
Determinants of Economic Growth in Nigeria: Population Perspective
}

\author{
Godwin Essang Esu ${ }^{1}$, Ubong Udonwa ${ }^{2}$ \\ ${ }^{1}$ Department of Economics, Faculty of Social Sciences, University of Uyo, Uyo, Nigeria \\ ${ }^{2}$ Department of Economics, Faculty of Sciences, University of Uyo, Uyo, Nigeria
}

Email address

essangabasi@yahoo.com (G. E. Esu), ubongudonwa@uniuyo.edu.org (U. Udonwa)

\section{To cite this article:}

Godwin Essang Esu, Ubong Udonwa. Determinants of Economic Growth in Nigeria: Population Perspective. Journal of World Economic Research. Vol. 5, No. 4, 2016, pp. 31-42. doi: 10.11648/j.jwer.20160504.12

Received: November 18, 2015; Accepted: March 11, 2016; Published: September 7, 2016

\begin{abstract}
There has been intense debate in the literature on what determines growth in an economy. Some scholars believe that increases in the population of a nation tantamount to economic progress, in that, it provides a huge base of labour force. However, others have argued that these increases could be a curse rather than a blessing, because if the increase in the number of people in the economy is not supported with conscious efforts at training and holistic development of human capital, then disaster is eminent. But a few scholars also believe that population assumes a neutral position in economic growth process, that is, population does not directly impact growth directly, but it interaction with other growth determinants (such as human capital development, research and development, technology and so on) is what actually determine growth or otherwise in the economy. This paper therefore sought to assess the role of these growth determinants in economic growth performance in Nigeria. The study employed time series data for the period 1981 - 2013. Using Augmented Cobb-Douglass Production Function (gleaning from Solow Growth Model), and relying on error correction modelling framework, the econometric results established the fact that population growth has the potentials of fostering economic growth in Nigeria, but underlined the fact that this and other benefits would depend on, not only the chunk of the entire population that is active, but the quality of the population. Amongst other policy options suggested, it was advocated that policy measures that will foster target-oriented and skill-enhancing education and training should be designed and implemented. Provision of accessible and affordable healthcare for a healthy population was also advocated if Nigeria's population growth must be advantageous.
\end{abstract}

Keywords: Population Growth, Economic Growth, Human Capital Development, Cointegration, ECM

\section{Introduction}

Nigeria is the most populous nation in Africa. It is the most populous black nation in the world, and indeed one of the highly populated nations of the Less Developed countries (LDCs). Nigeria's Population was 169. 28 million in 2013. It increased to 173.938 million in 2014 . This placed Nigeria the seventh most populous country in the world in 2014 (IMF, 2014).

To some scholars, continuous growth in population of the LDCs constitute a curse for a number of reasons: (1) a great number of the population is largely dependent and unproductive, (2) part of the population that is trained is relatively insignificant, and (3) the fraction of the population that has capacity to contribute to research and development (R\&D) that is, the development of technology, is relatively intangible (Cincotta and Engelman, 1997; Karev, 2002; Prettner and Trimbon, 2012). On the other hand, some scholars argue that population growth is very essential in the development process of LDCs, because labour or human capital is a major component in the production process. They however argue that population is a blessing if a large part of it constitutes a well - trained and informed human capital (Adewole, 2012; and Isola and Alani, 2012). The training involves investment in education and health, which has been found to be an effective way a nation's population can be moulded into a strong and active labour stock with productivity potentials. On this note, Uche, Ihugba and Nwosu (2013) argued that if government increases expenditure on education, with efficient management of the resources, it will result in a more viable human capital stock, and that will enhance productivity and growth. The 
objectives of this paper, therefore, are to investigate (i) the impact of increases in Nigeria's population on the growth performance of the Nigerian economy and (ii) the impact of the quality of population on economic growth performance.

This work is significant. Apart from the increasing demographic changes in recent times, the rising incidences of poverty and low per capita income necessitate the need for reinvestigating the outcomes of population growth economic growth interactions, both directly and indirectly. This is the focus of this paper.

The paper has five sections. Following the introduction is section 2, which focuses on stylised facts on some macroeconomic variables in Nigeria, it also reviews the literature. Section 3 highlight the methodology. In section 4, we analyse the data, interpret the results and discuss the findings. Conclusions and policy options are in section 5.

\section{Stylised Facts on Some Macroeconomic Variables in Nigeria}

i. Population (ages 15-65)

A productive population constitutes active, able-bodied, trained and healthy people. It is from this part of the population that unskilled, semi-skilled and skilled labours are drawn. This, coupled with the level of technology and available resources, determines the volume of a nation's output. Growth in active population in Nigeria (that is, ages 15 - 64) has been relatively stable for a large part of the period under investigation (1981 - 2013, see Figure 1).

Between 1981 and 2008, active population in Nigeria was below 54 million. It started rising in 2009 and assumed 60 million in 2010. In 2013, active population in Nigeria was above 60 million.

\section{ii. Human Capital}

For a country to have a productive population, substantial expenditure on education and health is imperative. In Nigeria's case, expenditure on human capital development has not been significant but in recent times. As indicated in Figure 2, between 1981 and 1996, human capital development received a very sluggish attention. Government expenditure on HCD stood at N0.3 million in 1981. However, gradual growth, though initially unstable, began in 1997 when government expended N22.1 million on HCD. In 2000, expenditure on HCD was N84.8 million and thence, it has been increasing.

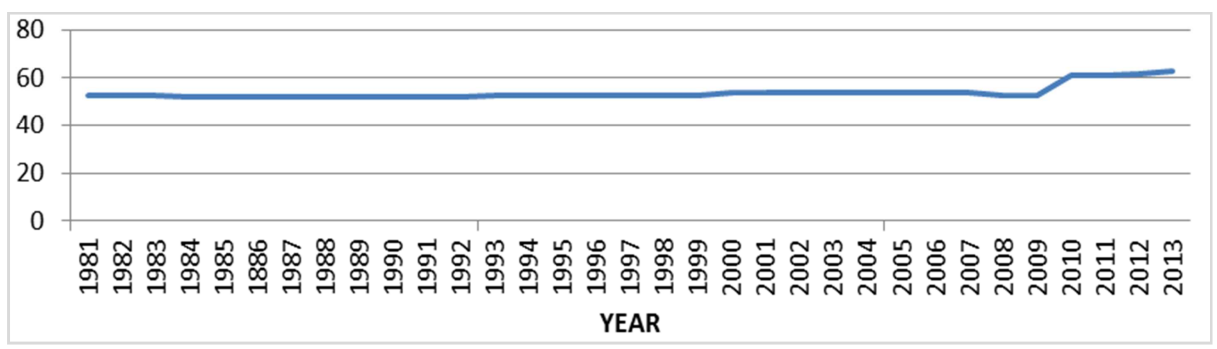

Source: WDI (2014)

Figure 1. Growth in Active Population in Nigeria \{ages 15 to 64(million)\} $1981-2013$.

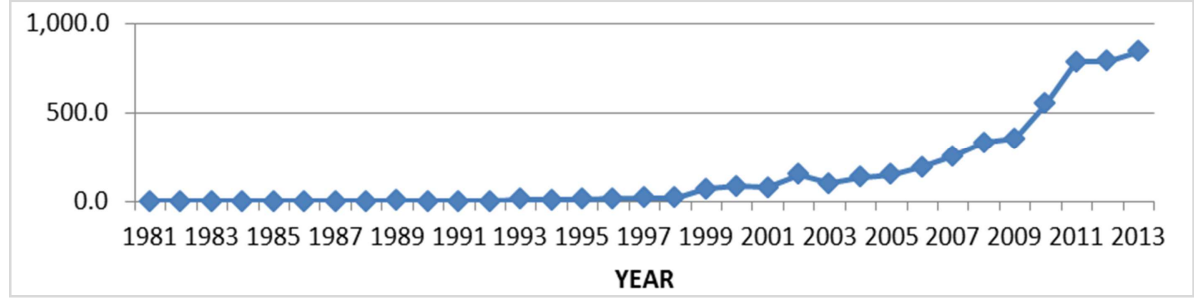

Source: WDI (2014)

Figure 2. Government Expenditure on Human Capital Development 1981 - 2013 (N'M).

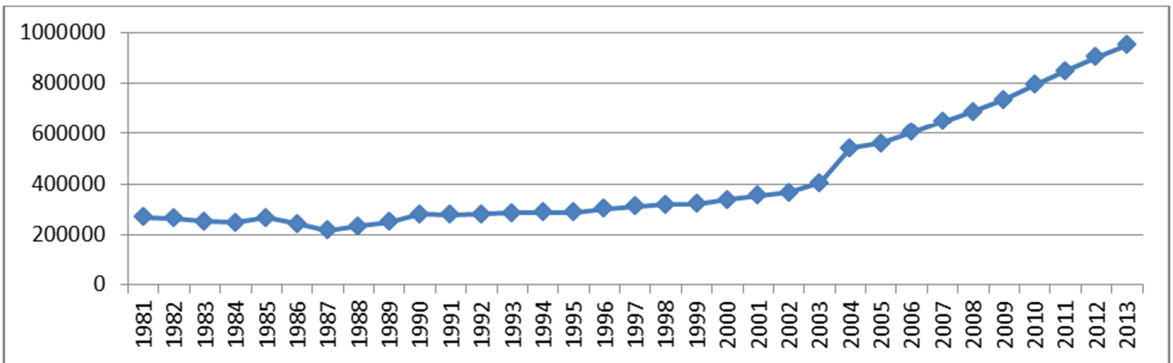

Source: authors' computation using data from CBN-SB, WDI (2014)

Figure 3. Real Gross Domestic Product, 1981 - 2013 (N'M). 


\section{iii. Real GDP}

Figure 3 shows the trend in Real Gross Domestic Product (RGDP) within the period under review. Between 1981 and 1995, growth in RGDP had not been significant. In 1981, RGDP stood at N268, 549 million and rose to N288, 619 million in 1995, indicating an increase of only N20, 070 million over that period. However, in 1996 RGDP assumed N303,032 million, and increased to N404, 904million in 2003. Thence, RGDP has been increasing steadily. In 2004, it was N541,503 million, while in 2013, it was N956,867.

A closer look at the trends in government expenditure on human capital development (HCD) and real gross domestic product within the period under review reveals a positive correlation between the variables. Between 1997 and 2003, government expenditure on HCD increased significantly above what it was between 1981 and 1996. The increase in government expenditure on HCD appears to have brought about increase in RGDP between the same period. More so, between 2003 and 2013, government expenditure on HCD increased more significantly (see fig. 2), this, again may have contributed to the astronomical increase in RGDP between 2003 and 2013 (see fig. 3).

\section{Review of Relevant Literature}

As Oser and Blanchfield (1975) pointed out, Adam Smith considered the endowments and skills acquired by residents of any country as part of the total capital stock of that country, since it raises the wealth of the people and the country at large. Campbell and Agbiokoro (2014) observed that, Thomas Malthus - relying on this argument - explained in his dynamic growth model that countries would always converge toward a stationary per capita income. That if incomes exceed the equilibrium point, death rate falls and fertility rate rises and vice versa. However, this prediction failed empirical testing in the nineteenth century, as Campbell and Agbiokoro (2014) pointed out. Fertility rate fell generally instead of increase as income rose at that time. The failure of Malthus hypothesis fueled the interest of the neoclassical economists to attempt modeling growth process with conscious avoidance of Malthus' linkage with population and the economy. The held that growth adjusts to investment rate in physical capital and not growth in population, thus like Becker, Murphy and Tamura (1994) indicated, they believed that the relationship between growth in physical capital stock and the growth in per capita income is highly disproportional.

After it was clear in the late $19^{\text {th }}$ century that both the early classical theory and neoclassical theory of growth could not survive the empirical scrutiny of the time, neoclassical economists came up in the literature with human capital theory in the 1960s. Solow (1956), Schultz (1961) and Grossman (1972), as pointed out by Campbell and Agbiokoro (2014), tried to establish the linkage of human capital with economic growth and the country by country development differences. In a bit to explain inter country divergences in growth, Solow (1956) growth theory underlined the fact that the rate of growth of any economy is a function of technological accumulation. Solow however ignored the fact that technology is driven by human capital; on its own, it has no capacity to translate into economic growth. Technology is engineered, developed, and improved upon by human capital; therefore, human capital remains the bedrock of sustainable development (Campbell and Agbiokoro, 2014).

Marquette (1997) examined the diversity of opinion, theory and conceptual approaches that characterize the discussion of population and its link with development, using environment as the transmission structure. Marquette (ibid) emphasized the fact that Malthus and Boserup did not address population - environment - growth beyond the narrow consideration of land use and food production. This notwithstanding, she underlined the fact that implications on general linkages between population and resources are frequently inferred from their work and their idea. Marquette (1997) had stressed that, Malthusian theory (1798 and 1803, republished 1960) had established that growth of human population tend always, to outweigh the productive capacities of land resources. The outcome is that 'positive' checks, such as famine and increased mortality, or preventive checks, such as postponement of marriage and limitation of family size, work to reduce population growth. Malthus suggested that population demands thus place direct limits on the availability of resources and that resources, in turn, place a direct restriction on population growth. Malthusian theory, formulated before the agricultural revolution, presumes that the productivity of environmental resources such as land is fixed. Malthus did not look beyond; he could not see the technological advances that would accompany modernisation.

Boserup (1965, 1976, 1981), on the other hand, considered technological change in her writing. Of course, her work was after the agricultural and industrial revolutions. She suggested that population growth and resulting increased population density 'induce' technological changes, for example the use of ploughs or fertilizer, which allow food production to keep pace with population growth (Marquette 1997). Boserup's theory became a robust advancement from the work of Malthus.

Hern $^{1}$ (1993) likened the population increase in the world to a plaque of cancer. To him, population increase is a threat to growth and stability of any nation. Hern (1993) argued that:

As the 20th century draws to a close, we find that we are being overwhelmed by our success as species. The human population grows without restraint, our activities are steadily destroying the global ecosystem in which we evolved, and we occupy and dominate all major ecosystems. We are no longer a few bands of inconsequential primates roving the grasslands of East

1 Dr. Hern is a physician and epidemiologist who specializes in population and human fertility issues, with the Institute of Behavioral science, University of Colorado, Boulder 
Africa as we were three million years ago. The human species, through the instrument of culture, has become the dominant force of planetary ecological change. Our adaptations have become maladaptive. Moreover, the human species as a whole now displays all four major characteristics of a malignant process: rapid, uncontrolled growth; invasion and destruction of adjacent normal tissues (ecosystems); metastasis (distant colonization); and dedifferentiation (loss of distinctiveness in individual components). We have become a malignant ecopathologic process. If this diagnosis is true, what is the prognosis?

He however reached a very interesting conclusion that, "the difference between humans and most forms of cancer is that humans can think, and can decide not to be a cancer."

Cohen (1995) examined the earth's capacity to carry the human population that is on the increase. In his work: Population Growth and Earth's Human Carrying Capacity, Cohen (1995) viewed the earth's capacity to support humanity as being determined by both natural constraints and human choices concerning economics, environment, culture (including values and politics), and demography.

This implies that if human beings would manage the economy, environment, culture (values and politics) and population better, earth's capacity to carry human population would increase; but if not, the capacity would decrease, and this will impede economic growth.

Bremner, López-Carr, Suter, and Davis (2010) also argued that continuous growth in population militates against economic growth through inducement of poverty, falling medical care/services, as well as environmental degradation. Health and educational needs of large number of children generally reduce household savings rates and reduce investments in production activities (Adewole 2012). Also, high fertility lowers female labour force participation and thus tends to decrease household income (Bremner et al, 2010). Finally, population growth may worsen resource scarcity in areas where a large proportion of the population already relies on natural resource-based livelihoods including, agriculture, grazing, forest products, and fishing for income and subsistence on marginal lands and less productive natural ecosystems (MEA, 2005 in Bremner et al, 2010). In addition to strain on the natural resource base, rising population also creates challenges for the equitable provisioning of adequate schooling, material resources, and civic order, thereby straining social conditions. Degraded social order impedes problem solving for environmental problems, causing further strain (Harte, 2007). Bremner et al (2010) therefore concluded that, empirical research on the impact of population growth on poverty is still largely inconclusive.

Ukpong, Ekpebu and Ofem (2013) also saw population growth as being inimical to economic growth through poverty aggravation. In their work entitled Cointegration Inferences on Issues of Poverty and Population Growth in Nigeria, they observed that poverty rate rises as population increased, implying that a rise in population will induce an increase in poverty level. Again, they found economic growth - poverty relationship to be negative, indicating economic growth - population growth negative relationship. ${ }^{2}$ It is therefore clear that population growth has been underlined as one of the main causes of poverty in most nations of the world, including Nigeria (WHES, 2012, IFAD, 2013).

Increased population mounts pressure on a nation by influencing the demand level of the people for essential needs of life. In a case where a nation's population growth is rapid, for example, the propensity that there would be a rise in demand for food, shelter, employment, infrastructure, healthcare, education will increase in the same direction, hence the consideration of rapid growth in population as a challenge on economic growth especially in the face of inadequate resources available (WHES, 2012). Ukpong et al (2013), on the other hand argued that:

Population growth remains a critical factor in the development of any economy and where not properly managed, could inflate the scourge of poverty in the economy... population growth can be a useful factor in providing a workforce for the production of goods and services to boost economic development, and remains a critical determinant of the potential of a country's investment..., increase in population alone may not increase poverty incidence in a country, considering the development in China, and other countries, that have noticed considerable economic growth over the last decades despite their large population size.

Some scholars have argued and attempted to establish empirically, that population increase is not a problem in itself to any nation, and that there are some impeding factors associated with population growth such as, corruption, inadequate planning, inappropriate implementation of development plans, poor budget/implementation, complacency in developing human capital. Adetiloye and Adeyemo (2012) in the same vein argued that high population growth in an economy with falling and/or inadequate real investment in assets and capital formation (which include investment in education and health) will lead to increased poverty and negative economic growth.

Adewole (2012) in his work: Effect of Population on Economic Development in Nigeria: A quantitative Assessment. argued that "the consequences of a rapidly increasing population are to retard all development efforts in Nigeria unless accompanied by high rate of capital accumulation and technological progress." Schutz (1961; 1992) and Dennis (1962) argued that quality of population is the crucial factor of production and that this quality can only be a product of investment on education and health. Bloom and Canning (2003) supported this assertion on the grounds that health is a direct component of man's wellness as well as part of human capital set that builds individual's capabilities. Isola and Alani (2012) lent support to developed human capital as agent of national development in any country of the

2 Poverty is the transmission mechanism that establishes the economic growth population growth relationship described above. 
world. Adapting growth accounting model in their work: Human Capital Development and Economic Growth: Empirical Evidence from Nigeria, their findings showed that a growth in qualitative population set will only amount to improvement in the economic wellbeing of Nigeria. Grossman (1972), Schultz (1992), Bloom and Canning (2000 and 2003), and Isola (2002) variously argued that the quality desired - which can translate into economic growth - is only a question of ensuring an educated and a healthy population.

Adelakun (2011) held that Nigeria need not to really worry about the increase in the population size, but should rather engage pragmatic approach in developing their capabilities, since it should be considered a very veritable economic growth transmitter. He explained that human capital remains the rallying point where all resources are converted into functional forms for man's use and benefit. In his work, Human Capital Development and Economic Growth in Nigeria, Adelakun (2011) found a positive relationship between human capital development and economic growth for Nigeria, arguing that the percentage of this relationship, though significant, was not strong due to a high degree of illiteracy and healthcare shortage. Also, Awe and Ajayi (2010) fund a positive relationship and a directional causation for human capital investment and economic growth, but with a strong call for conscious and pragmatic investment in education and health. Prettner and Trimbon (2012) argued and emphasized the fact that building a viable human capital is a necessary, but not a sufficient condition for gaining from population growth. They stressed that, a viable labour stock at all levels, has to grow progressively with the growth in the manufacturing sector together with a deepening technology through R\&D. Thus, any demographic change without growth in production and technological progress may result in poverty (that is, fall in per capita income), high degree of dependency, inequality, and dwindling economic progress.

In analysing economic growth fluctuations vis-à-vis population growth in Nigeria, Nwosu, Dike and Okwara (2014) found a positive (significant) impact of population growth on economic growth. Employing time series data spanning 1960 to 2008, they found out that, apart from the significant impact, there is a long run equilibrium relationship between economic growth and population growth and also, an indication of unidirectional causality between these variables. Their conclusions further affirm the argument that population growth in itself is not a curse, since all other resources required for economic growth are driven by the availability of human capital. The implication of this is that, how much any country can benefit from its population size is dependent on the quality of human capital. Where human capital development efforts are dwindling in the face of increasing population, then adverse consequences on economic growth should be expected (Nwosu et al., 2014). This is because a growing population size without corresponding growth in the development of human capital will only increase rate of dependence and consumption, and will bring about falling rate of household savings, falling rate of per capita income as well as very low productivity.

From the foregoing, we infer that economic growth of a nation could be dependent on the growth of its population, but the effect or impact can be either negative or positive depending on the availability of certain factors and conditions - improved technology (R \& D), functional HCD programmes, and adequate and functional infrastructure.

\section{Methodology}

\subsection{Model Specification}

In the literature, it is clear that the contribution of any country's population to its economic growth performance is measured in terms of productivity. Earlier in neoclassical model, human capital was not seen as a prominent input in the production process and as such was not part of the growth model. Solow (1956) became the foremost work with the consciousness of the importance of human capital in growth model. He included human capital as one of the vital explanatory variables in his model. In the model, growth in national output is dependent on three factors namely, increase in physical capital stock, increase in the size of labour force, and a residual which incorporates all other factors (the component which address technological progress or total factor productivity). Solow employed the aggregate production function which is continuous and homogenous and is expressed as:

$$
\mathrm{Y}=\mathrm{f}(\mathrm{K}, \mathrm{L}, \mathrm{T})
$$

Where $\mathrm{Y}$ is output, $\mathrm{K}$ is capital stock, $\mathrm{L}$ is labour force (which is a component of the entire population) and $\mathrm{T}$ is technology. The model assumes a constant return to scale, so labour productivity $(\mathrm{y} \equiv \mathrm{Y} / \mathrm{L})$ in the model is a function of capital intensity $(\mathrm{k} \equiv \mathrm{K} / \mathrm{L})$. As such, the relationship between each unit of labour and capital in production does not vary with the variation in the quantity of labour and capital in the economy. The aggregate production function implicit in this model assumes diminishing returns on capital accumulation. The Cobb-Douglass production function explicitly expresses the relations in (1), thus:

$$
\mathrm{Y}=\mathrm{K}^{\lambda} \mathrm{L}^{1-\lambda} \mathrm{T}, 0<\boldsymbol{\lambda}<1
$$

Implying that labour productivity increases if there is a rise in capital intensity (i.e capital deepening or increase). The model is therefore amendable for our purpose for its labour (human capital) component. Employing the production function approach, the model states that output growth (RGDP) is principally determined by the following factors: the rate of growth of labour and/or the rate of growth of its quality, multiplied by the labour income share; the rate of growth of gross capital (physical) input and/or the rate of growth of its quality, multiplied by the capital income share; and change in technology $(\mathrm{T})$ or total factor productivity (TFP) of which impact of technological change is captured and is also regarded as efficiency parameter. In line with the forgoing and for robustness of investigation this work 
pursued, Augmented Cobb-Douglass production function was employed and is given as:

$$
\begin{aligned}
& Y=f\left(A K^{\lambda_{1}} L^{\lambda_{2}}\right) \\
& Y=A K^{\lambda_{1}} L^{\lambda_{2}} e^{\mu}
\end{aligned}
$$

Where $\mathrm{Y}$ is output (RGDP); $\mathrm{L}$ is labour (a component of the country's population size - LAB); $\mathrm{K}$ is capital formation/investment (which gross fixed capital formation GFCF - is a proxy), $\mathrm{e}^{\mu}$ is the natural $\log$ of the residuals and $\mathrm{A}$ is total factor productivity (TFP) - the efficiency parameter. While capital and labour (proxied by percentage of the population between ages 15 and 65), are endogenous part of the function (following theory), other variables like human capital development (HCD) (proxied by government expenditure on education and health), final consumption expenditure(CONEXP), exchange rate (EXR), and inflation (INF), are implicitly assumed to establish the behaviour of TFP. Thus, the TFP was specified as:

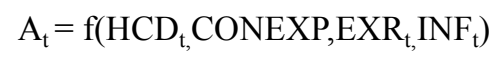

Where final consumption expenditure, exchange rate and inflation are incorporated as intervening variables. Equation (4) above can therefore be stated as below for purpose of stability:

$$
\begin{gathered}
\operatorname{RGDP}_{\mathrm{t}}=\gamma_{\mathrm{t}}, \mathrm{CAP}_{\mathrm{t}}{ }^{1}, \mathrm{LAB}_{\mathrm{t}}{ }^{{ }^{2}} \\
\operatorname{HCD}_{\mathrm{t}}{ }^{{ }^{3}} \operatorname{CONEXP}_{\mathrm{t}}{ }^{4} \operatorname{EXR}_{\mathrm{t}}{ }^{5} \operatorname{INF}_{\mathrm{t}}{ }^{6}
\end{gathered}
$$

However, in an attempt to deepen our investigation of the role of population growth on Nigeria's economic growth performance, we considered equations that will examine the impacts RGDP receive using a disaggregated approach. Thus, we evaluate the contributions on agricultural and manufacturing subsectors apart from the aggregated equation, since this disaggregated evaluation will give clearer picture of growth behaviour. Thus, the econometric specifications from equation (5) are thus

$$
\begin{gathered}
\operatorname{lnRGDP}=\gamma_{\mathrm{t}}+\boldsymbol{\lambda}_{1} \operatorname{lnCAP} \mathrm{t}_{\mathrm{t}}+\boldsymbol{\lambda}_{2} \operatorname{lnLAB} \mathrm{AB}_{\mathrm{t}}+\boldsymbol{\lambda}_{3} \operatorname{lnHCD}_{\mathrm{t}} \\
+\boldsymbol{\lambda}_{4} \operatorname{lnCONEXP}_{\mathrm{t}}+\boldsymbol{\lambda}_{5} \operatorname{lnEXR}_{\mathrm{t}}+\boldsymbol{\lambda}_{6} \mathrm{INF}_{\mathrm{t}}+\boldsymbol{\omega}_{\mathrm{t}} \\
\operatorname{lnRGDP}(\text { Manu. })=\gamma_{\mathrm{t}}+\boldsymbol{\lambda}_{1} \operatorname{lnCAP}_{\mathrm{t}}+\boldsymbol{\lambda}_{2} \operatorname{lnLAB}_{\mathrm{t}}+\boldsymbol{\lambda}_{3} \operatorname{lnHCD}_{\mathrm{t}} \\
+\boldsymbol{\lambda}_{4} \operatorname{lnCONEXP}_{\mathrm{t}}+\boldsymbol{\lambda}_{5} \operatorname{lnEXR}_{\mathrm{t}}+\boldsymbol{\lambda}_{6} \mathrm{INF}_{\mathrm{t}}+\boldsymbol{\omega}_{\mathrm{t}} \\
\operatorname{lnRGDP}(\text { Agric. })=\gamma_{\mathrm{t}}+\boldsymbol{\lambda}_{1} \operatorname{lnCAP}_{\mathrm{t}}+\boldsymbol{\lambda}_{2} \operatorname{lnLAB}_{\mathrm{t}} \boldsymbol{\lambda}_{3} \operatorname{lnHCD}_{\mathrm{t}} \\
+\boldsymbol{\lambda}_{4} \operatorname{lnCONEXP}_{\mathrm{t}+} \boldsymbol{\lambda}_{6} \operatorname{lnEXR}_{\mathrm{t}}+\boldsymbol{\lambda}_{6} \mathrm{INF}_{\mathrm{t}}+\boldsymbol{\omega}_{\mathrm{t}}
\end{gathered}
$$

\footnotetext{
3 Kareem et al (2012) and Esu (2015) took the same position in estimating a similar model and attempting stability there with.

4 The absence of POP in equation (8) explains the fact that manufacturing sector is of characterized by the employment of mostly skilled labour a few semi-skilled labour.

5 POP replaced LAB in the production function because of the capacity for large scale employment of both skilled, semi-skilled and unskilled labour in the agricultural sector.
}

A priori, therefore, $\frac{\partial R G D P}{\partial C A P}>0, \frac{\partial R G D P}{\partial L A B}>0, \frac{\partial R G D P}{\partial H C D}>0$, $\frac{\partial R G D P}{\partial C O N E X P}>0, \frac{\partial R G D P}{\partial E X R} \gtrless 0, \frac{\partial R G D P}{\partial I N F} \gtrless 0$

$\gamma_{\mathrm{t}}$ represents a constant parameter, $\boldsymbol{\omega}_{\mathrm{t}}$ denotes the stochastic disturbance term and other variables are as earlier defined. The $\lambda_{\mathrm{i}}$ represents the vector of the elasticities of the coefficients of the variables earlier defined and a priori signs are expected to be positive but for inflation and population size that are indeterminate. The econometric models are expressed in double log for ease of interpretation and to make equation (5) amendable for Ordinary Least Squares (OLS) estimation.

\subsection{Description of Data and Sources}

In order to check if there is a robust relationship between economic growth performance and population growth, with focus on the Nigerian economy, real gross domestic product (RGDP) was used as proxy for economic growth performance, and was extracted from World Development Indicators (WDI, 2014). Gross fixed capital formation (GFCF) proxied capital (CAP) while the part of the population within the official active age (15-64) was used to capture the size of labour (LAB) within the growing population. The sources are Central Bank of Nigeria Statistical Bulletin (CBN, 2013) and (WDI, 2014). Other variables: real (final) consumption expenditure (CONEXP), exchange rate (EXR) and inflation (INF), were all extracted from CBN Statistical Bulletin (2013) and WDI (2014).

\subsection{Estimation Technique}

The numerical estimates of the coefficients in the equations above were obtained using OLS technique, with the aid of a software application (e-views version 8). As is standard in the literature, the OLS method was chosen because of its property of being best linear unbiased estimator (BLUE). In order to manage the misleading characteristics of macroeconomic variables in time series analysis, we assessed the time series properties of the variables under investigation employing the Augmented Dickey-Fuller (ADF) test for unit root, which involves running the following regression:

$$
\Delta Y_{t}=\beta_{1}+\beta_{2} t+\delta Y_{t-1}+\sum_{i=1}^{m} \propto_{i} \Delta Y_{t-i}+\varepsilon_{t}
$$

Where $\mathrm{Y}_{\mathrm{t}-\mathrm{i}}$ is the vector of relevant variables under examination and $\varepsilon_{\mathrm{t}}$ represents stochastic error term. The optimal lag period is selected sizeable enough (applying the Schwarz Information Criterion) to ensure that $\varepsilon_{\mathrm{t}}$ is not autocorrelated (white noise). The null hypothesis is that the time series has a unit root $\left(\mathrm{H}^{0}: \delta=0\right)$ and the alternate is that the time series is trend stationary $\left(\mathrm{H}_{1}: \delta<0\right)$. The null hypothesis of non-stationarity is rejected if the computed Augmented Dickey-Fuller t-statistic is greater than critical tau-value.

It is important to note that unit roots test type like the Dickey-Fuller and Augmented Dickey-Fuller (to some extent) are structural breaks sensitive. Such tests confuse structural breaks with non-stationarity (Geda, Ndung'u and 
Zerfu, 2012). This means that a truly stationary variable with structural breaks may be identified as non-stationary. However, we adopt the Phillip-Perron (PP) tests developed by Perron (1997) for its properties that enhance its capacity to handle these shocks. Herzer, Nowark-Lehmann and Silverstove (2004) and Akpan (2011) also noted that, the test examines the time series properties in the presence of structural changes at random (unknown) points in time, thereby internalising the structural breaks. The specification is thus:

$$
t_{\pi}^{*}=t_{\pi}\left[\frac{\gamma_{o}}{f_{o}}\right]^{\frac{1}{2}}-\frac{K\left(f^{o}-\gamma^{o}\right)[s e(\widehat{\pi})]}{2 f_{o} \frac{1}{2} s}
$$

Where $\hat{\pi}$ is the estimate, and $t_{\pi}$ is the t-ratio of $\pi$, se $(\hat{\pi})$ is the coefficient standard error, and $s$ is the standard error of the regression equation. Also, $\gamma_{o}$ is a consistent estimate of the error variance, while $f_{o}$ is the residual spectrum at frequency zero.

After examining the stationarity status of the time series, we employed the Johansen conintegration test technique to ascertain the cointegration or otherwise of the variables, that is, if there was a long run equilibrium relationship among the variables. Simply put, it is to ascertain if the combination of the time series can produce meaningful result in the long run.

\subsection{Error Correction Model (ECM)}

Obviously, once co-integration or long run relationship is established in any of the specifications above, then the need for error correction arises traditionally, hence the employment of error correction mechanism, using error correction model (ECM). The error correction mechanism (ECM) corrects for disequilibrium. It was first used by Sargen (1984) and popularised by Engle and Granger. An important theorem, according to Gujarati (2003), known as the Granger representation theorem, states that if two variables $\mathrm{Y}$ and $\mathrm{X}$ are cointegrated, then the relationship between the two can be expressed as ECM. For instance, from the equation (6) above, if RGDP and POP are cointegrated of the order 1(1), the ECM can be specified as:

$$
\Delta R G D P_{t}=\partial_{1}+\partial_{2} \Delta P O P_{t}+\partial_{3} \omega_{t-1}+\delta_{t}
$$

Where $\Delta$ denotes the first difference operator, $\delta_{t}$ is the random error term, and $\boldsymbol{\omega}_{\mathrm{t}-1}=\left(\mathrm{RGDP}_{\mathrm{t}-1}-\boldsymbol{\lambda}_{1}-\boldsymbol{\lambda}_{2} \mathrm{POP}_{\mathrm{t}-1}\right)$, that is, the one period lagged value of the error from the cointegrating regression hypothesized.

\section{Empirical Results and Analysis}

Following an examination of the data, the diagnostic test results are presented in Tables 1 and 2. The two consistently used test statistic for the unit root - ADF and PP test - were employed and the results indicate that, for ADF, most variables were non-stationary at level, but at first difference and at $10 \%, 5 \%$ and $1 \%$ levels of significance as presented in Table 1.

Table 1. Test Results for Unit Root (Regression with Intercept and Deterministic Trend).

\begin{tabular}{llllll}
\hline Variable & ADF Statistic & & PP Statistic & \\
\hline & Level & $1^{\text {st }}$ Difference & Level & $1^{\text {st }}$ Difference & Decision \\
$\ln ($ RGDP $)$ & $-1.5014(0.8074)$ & $-5.0275(0.0017) * * *$ & $-1.4662(0.8196)$ & $-5.1030(0.0014) * * *$ & $1(1)$ \\
$\ln ($ RGDP manu. $)$ & $-2.3104(0.1452)$ & $-5.9988(0.0002) * * *$ & $-1.2161(0.7216)$ & $-6.8161(0.0000) * * *$ & $1(1)$ \\
$\ln ($ RGDP Agric) & $-1.5142(06147)$ & $-7.7325(0.0000) * * *$ & $-2.4716(0.4451)$ & $-5.8932(0.0000) * * *$ & $1(2) / 1(1)$ \\
$\operatorname{Ln}($ CAP $)$ & $-3.0847(0.1274)$ & $-4.7499(0.0036) * * *$ & $-3.0790(0.1287)$ & $-4.5302(0.0058) * * *$ & $1(1)$ \\
$\ln ($ LAB $)$ & $-7.5689(0.0000) * * *$ & - & - & - & $1(0)$ \\
$\ln ($ HCD $)$ & $-4.1355(0.0142) * *$ & $-5.2754(0.0011) * * *$ & $-4.0787(0.0161) *$ & $-12.3867(0000) * * *$ & $1(0) / 1(1)$ \\
$\ln ($ CONEXP) & $-2.5910(0.2865)$ & $-6.5692(0.0000) * * *$ & $-2.6681(0.2555)$ & $-9.2622(0.0000) * * *$ & $1(1)$ \\
$\ln$ EXR & $-1.4729(0.8173)$ & $-3.3489(0.0778) *$ & $-1.5484(0.7900)$ & $-3.5635(0.0505) * *$ & $1(1)$ \\
$I N F$ & $-3.5710(0.0497) *$ & $-5.5373(0.0000) * * *$ & $-2.5527(0.3027)$ & $-9.1049(0.0000) * * *$ & $1(0) / 1(1)$ \\
\hline
\end{tabular}

Note:*,** and $* * *$ denote significance at $10 \%, 5 \%$ and $1 \%$ respectively. Values in bracket - for ADF and PP - statistic are P-values. All tests include individual intercept and deterministic trend. ADF and PP tests are taken from Mackinnon (1996) as report by E-views, version 8.0.

Table 1 shows that ADF results for RGDPs, CAP, HCD, CONEXP, EXR and INF were all stationary at first difference, at $1 \%$ significant level except EXR that was stationary at $10 \%$ level of significance. Other variables were stationary at level at $10 \%, 5 \%$ and $1 \%$ level of significance with inflation reflecting a mixed situation. Inflation was found to be stationary at level and at first difference at $10 \%$ and $1 \%$ level of significance, respectively. However, PP test produced a more reliable result with all the variables - except $\mathrm{LAB}$ and $\mathrm{HCD}$ - being stationary at first difference and predominantly at $1 \%$ significant level. LAB was, however, found to be nonstationary both at levels and first difference, - a situation found to be relatively unique - which also explained its stationarity only at levels in the case of ADF. This situation can be attributed to a few factors, chief among them are; first, the gross unemployment/underemployment that plaques that part of the population, thereby affecting its impact despite the size of the (active) population. The second is the clear data inconsistency/non-availability coupled with poor quality of the available ones. All evaluation was done based on P-values. ${ }^{6}$ The results in table 1 pointed to the need to investigate the evidence of cointegration among the modelled variables and the results are presented in tables $2 \mathrm{a}-\mathrm{c}$.

6 The P. value indicatess the exact level of significance of the variable. It is the exact value at which the null hypothesis is rejected. See Gujarati (2009). 
Table 2a. Summary of Johansen Cointegration Test Result (General Assessment Model).

\begin{tabular}{llllll}
\hline & Trace & Test & & Maximum-Eigen & Test \\
\hline Hypo. No. of CE(s) & Critical Value & Trace Statistic & Hypo. No. of CE(s) & Critical Value & Max-Eigen Statistic \\
\hline $\mathrm{r}=0 *$ & 159.5297 & $559.60539(0.0000) * * *$ & $\mathrm{r}=0 *$ & 52.3626 & $199.6292(0.0001) * * *$ \\
$\mathrm{r} \leq 1 *$ & 125.6154 & $359.9761(0.0000) * * *$ & $\mathrm{r} \leq 1 *$ & 46.2314 & $172.7501(0.0000) * * *$ \\
$\mathrm{r} \leq 2 *$ & 95.7536 & $187.2260(0.0000) * * *$ & $\mathrm{r} \leq 2 *$ & 40.0775 & $79.5417(0.0000) * * *$ \\
$\mathrm{r} \leq 3 *$ & 69.8188 & $107.6843(0.0000) * * *$ & $\mathrm{r} \leq 3 *$ & 33.8768 & $39.9384(0.0084) * * *$ \\
$\mathrm{r} \leq 4 *$ & 47.8561 & $67.7458(0.0003) * * *$ & $\mathrm{r} \leq 4 *$ & 27.5843 & $30.3682(0.0214)^{* * *}$ \\
$\mathrm{r} \leq 5 *$ & 29.7970 & $42.7104(0.0010) * * *$ & $\mathrm{r} \leq 5 *$ & 21.1316 & $21.6672(0.0420) * * *$ \\
$\mathrm{r} \leq 6 *$ & 15.4947 & $21.0431(0.0066) * * *$ & $\mathrm{r} \leq 6 *$ & 14.2646 & $14.5684(0.0448)^{* * *}$ \\
$\mathrm{r} \leq 7 *$ & 3.8414 & $8.8953(0.0029) * * *$ & $\mathrm{r} \leq 7 *$ & 3.8414 & $3.8414(0.0029) * * *$ \\
\hline
\end{tabular}

Note: $\mathrm{r}$ represents the number of hypothesized cointegrating equations. * denotes the cointegrated equations and $* * *$ signifies asymptotic significance at $5 \%$ significant level. P-values are presented in brackets, as seen in the table above. The estimation was done using E-views, version 8.0

Table 2b. Summary of Johansen Cointegration Test (Assessment of the Manufacturing Sector).

\begin{tabular}{llllll}
\hline & Trace & Test & & Maximum-Eigen & Test \\
\hline Hypo. No. of CE(s) & Critical Value & Trace Statistic & Hypo. No. of CE(s) & Critical Value & Max-Eigen Statistic \\
\hline $\mathrm{r}=0 *$ & 159.5297 & $618.2897(0.0000) * * *$ & $\mathrm{r}=0 *$ & 52.3626 & $238.5686(0.0001) * * *$ \\
$\mathrm{r} \leq 1 *$ & 125.6154 & $379.7211(0.0000) * * *$ & $\mathrm{r} \leq 1 *$ & 46.2314 & $129.5060(0.0000) * * *$ \\
$\mathrm{r} \leq 2 *$ & 95.7536 & $250.2151(0.0000) * * *$ & $\mathrm{r} \leq 2 *$ & 40.0775 & $79.97471(0.0000) * * *$ \\
$\mathrm{r} \leq 3 *$ & 69.8188 & $170.2404(0.0000) * * *$ & $\mathrm{r} \leq 3 *$ & 33.8768 & $69.92824(0.0000) * * *$ \\
$\mathrm{r} \leq 4 *$ & 47.8561 & $100.3122(0.0000) * * *$ & $\mathrm{r} \leq 4 *$ & 27.5843 & $40.41100(0.0007)^{* * *}$ \\
$\mathrm{r} \leq 5 *$ & 29.7970 & $59.90116(0.0000) * * *$ & $\mathrm{r} \leq 5 *$ & 21.1316 & $26.13965(0.0091) * * *$ \\
$\mathrm{r} \leq 6 *$ & 15.4947 & $33.76151(0.0000) * * *$ & $\mathrm{r} \leq 6 *$ & 14.2646 & $22.52783(0.0020)^{* * *}$ \\
$\mathrm{r} \leq 7 *$ & 3.8414 & $11.23368(0.0008) * * *$ & $\mathrm{r} \leq 7 *$ & 3.8414 & $11.23368(0.0008) * * *$ \\
\hline
\end{tabular}

Note: $\mathrm{r}$ represents the number of hypothesized cointegrating equations. $*$ denotes the cointegrated equations and $* * *$ signifies asymptotic significance at $5 \%$ significant level. P-values are presented in brackets, as seen in the table above. The estimation was done using E-views, version 8.0

Table 2c. Summary of Johansen Cointegration Test (Assessment of the Agricultural sector).

\begin{tabular}{llllll}
\hline & Trace & Test & \multicolumn{3}{l}{ Maximum-Eigen Test } \\
\hline Hypo. No. of CE (s) & Critical Value & Trace Statistic & Hypo. No. of CE (s) & Critical Value & Max-Eigen Statistic \\
\hline $\mathrm{r}=0 *$ & 159.5297 & $589.9345(0.0000) * * *$ & $\mathrm{r}=0 *$ & 52.3626 & $267.6457(0.0001) * * *$ \\
$\mathrm{r} \leq 1 *$ & 125.6154 & $322.2888(0.0000) * * *$ & $\mathrm{r} \leq 1 *$ & 46.2314 & $126.7277(0.0000) * * *$ \\
$\mathrm{r} \leq 2 *$ & 95.7536 & $195.5611(0.0000) * * *$ & $\mathrm{r} \leq 2 *$ & 40.0775 & $60.34247(0.0001) * * *$ \\
$\mathrm{r} \leq 3 *$ & 69.8188 & $135.2186(0.0000) * * *$ & $\mathrm{r} \leq 3 *$ & 33.8768 & $46.49594(0.0010) * * *$ \\
$\mathrm{r} \leq 4 *$ & 47.8561 & $88.72268(0.0000) * * *$ & $\mathrm{r} \leq 4 *$ & 27.5843 & $29.03773(0.0323)^{* * *}$ \\
$\mathrm{r} \leq 5 *$ & 29.7970 & $59.68459(0.0000) * * *$ & $\mathrm{r} \leq 5 *$ & 21.1316 & $27.78983(0.0050) * * *$ \\
$\mathrm{r} \leq 6 *$ & 15.4947 & $31.89512(0.0001) * * *$ & $\mathrm{r} \leq 6 *$ & 14.2646 & $22.88120(0.0017)^{* * *}$ \\
$\mathrm{r} \leq 7 *$ & 3.8414 & $9.013918(0.0027) * * *$ & $\mathrm{r} \leq 7 *$ & 3.8414 & $9.013918(0.0027) * * *$ \\
\hline
\end{tabular}

Note: $\mathrm{r}$ represents the number of hypothesized cointegrating equations. * denotes the cointegrated equations and $* * *$ signifies asymptotic significance at $5 \%$ significant level. P-values are presented in brackets, as seen in the table above. The estimation was done using E-views, version 8.0

As shown in Tables 2a-c, it was clear that long run equilibrium relationship exists among the variables. This further enunciates the fact that a short run dynamics using the error correction framework was required. Also, it is conventional in econometric literature that the existence of a long run relationship forms the basis for evaluating the short run distortions associated with the equilibrium relationship. Again, it is reasonable to be conscious of the fact that, for any equilibrium relationship, short run disequilibrium is possible. This explains why Gemmell (1990) and Manning and Adriacanos (1993) argued that in a situation where evidence of cointegration cannot be clearly established among variables, it may still be necessary to examine their short-run relationships. As Akpan (2011) observed, the argument is that though a long- run relationship cannot be established among variables for a given time period, it may still be possible that they are causally related in the short-run. To examine the short-run dynamics in the model, equation (6) was reparamatised, resulting in error correction model (ECM). The model indicates distortions in the long-run equilibrium caused by shocks in the model as well as the period required for adequate adjustment from disequilibrium to take place. The estimate of the ECM is presented in Table 3.

The result of the short-run dynamics presented in Table 3 throws up basic clues to the possible dynamic roles population growth can play in economic growth performance of Nigeria irrespective of a few conflicting statistical behaviours. Generally, the error correction terms (ECTs) in 
all the models conform significantly to theoretical sign, showing that the speed of adjustment to long-run equilibrium is reasonably fast. The adjusted R-squared for models 1,2 , and 3 show a robust explanatory power of the modeled variables. As Table 3 reflects, the Adjusted R-squared, in model 1, indicated that about 54.31 percent variation in economic growth (Real GDP) is jointly explained, by the modeled variables (that is, CAP, LAB, HCD, CONEXP, EXR and INF). That is, the variables in the model can only explain about 54.31 percent of the growth in the Nigerian economy within the period under investigation. The table also shows that Models 2 and 3 had Adjusted R-squared of 69.90 percent and 73.81 percent respectively, indicating that the variables in the models could jointly explain about 69.90 percent and 73.81 percent variations in manufacturing and agricultural outputs respectively. This, by extension, reflects the contributions of these subsectors to national growth. The overall significance of the models was clearly shown by the significance of the F-statistic (which were 5.4587, 9.7089 and 11.5703 respectively), highlighting the fact that the models are good fits.

Table 3. The Result of the Dynamic Short-run Model (ECM).

\begin{tabular}{|c|c|c|c|c|c|c|}
\hline Dependent Variable: & $\Delta \log \left(\right.$ RGDP $\left._{t}\right)$ & & $\Delta \log ($ RGDF & & $\Delta \log ($ RGD & $\left.\mathrm{ric}_{\mathrm{t}}\right)$ \\
\hline \multirow{2}{*}{ Independent Variable: } & \multicolumn{2}{|l|}{ Model 1} & \multicolumn{2}{|l|}{ Model 2} & \multicolumn{2}{|l|}{ Model3 } \\
\hline & Coefficient & Standard Error & Coefficient & Standard Error & Coefficient & Standard Error \\
\hline Constant & -0.4076 & 0.3487 & -0.4060 & 0.9830 & -0.0858 & 0.1520 \\
\hline$\Delta \log \left(\mathrm{CAP}_{\mathrm{t}}\right)$ & $0.1119 *$ & 0.0586 & 0.0939 & 0.1901 & $0.0433 * *$ & 0.0199 \\
\hline$\Delta \log \left(\mathrm{LAB}_{\mathrm{t}}\right)$ & -1.6716 & 5.1199 & $1.0687 * *$ & 0.4059 & -3.6873 & 2.1895 \\
\hline$\Delta \log \left(\mathrm{HCD}_{\mathrm{t}}\right)$ & 0.0141 & 0.0119 & $-0.0881 * *$ & 0.0499 & $0.0122 * *$ & 0.0052 \\
\hline$\Delta \log \left(\mathrm{CONEXP}_{\mathrm{t}}\right)$ & $0.3504 * * *$ & 0.0755 & $-0.9909 * * *$ & -2.9018 & $0.0968 * * *$ & 0.0310 \\
\hline$\Delta\left(\mathrm{EXR}_{\mathrm{t}}\right)$ & $0.0003 * *$ & 0.0001 & $0.0010 * *$ & 0.0005 & $-0.0004 * * *$ & 6.1405 \\
\hline$\Delta\left(\mathrm{INF}_{\mathrm{t}}\right)$ & -0.0003 & 0.0007 & $0.0073 * * *$ & 0.0023 & -0.0003 & 0.0002 \\
\hline $\mathrm{ECT}_{\mathrm{t}-1}$ & $-0.7089 * *$ & 0.2077 & $-0.8651 * * *-$ & 0.1766 & $-0.3685 * * *$ & 0.1931 \\
\hline R-Sqd & 0.664991 & - & 0.779275 & - & 0.807965 & - \\
\hline Adj. R-Sqd & 0.543170 & - & 0.699011 & - & 0.738134 & - \\
\hline F-Statistic & 5.4587 & $(0.0007) * * *$ & 9.708920 & $(0.000011) * * *$ & 11.57030 & $(0.000003) * * *$ \\
\hline D-W & 1.728664 & - & 2.217706 & - & 1.918469 & - \\
\hline JB & 172.2173 & $(0.000) * * *$ & 19.3045 & $(0.000064) * * *$ & 2.9193 & $(0.232313)$ \\
\hline B.G. LM Test & 2.5976 & $(0.0982) *$ & 0.3587 & $(0.7030)$ & 1.548483 & $(0.2370)$ \\
\hline RESET Test & 1.7659 & $(0.1975)$ & 0.7979 & $(0.3818)$ & 0.0357 & $(0.9718)$ \\
\hline B-P-G & 12.2517 & $(0.0926) *$ & 2.605371 & $(0.0359) * *$ & 1.811996 & $(0.1287)$ \\
\hline
\end{tabular}

Note: $* * *, * *$ and $*$ indicate $1 \%, 5 \%$ and $10 \%$ person significant levels respectively. $\Delta$ denotes first difference operator and P-values are in brackets.

The Durbin-Watson (D-W) statistic for the three models suggests the absence of partial serial correlation in the models. The Jarque Bera (J.B) F-statistic (172.2173, 19.3045) further confirmed this conclusion for models 1 and 2. The J.B F-statistic is statistically significant, implying that the estimated residuals are normally distributed. However, the non-normality reflected in the case of model 3 may be attributed to the case of inherent distortions in Nigerian data. Though Breusch-Godfrey LM test result suggests the presence of serial correlation in the residuals, the robustness of the D-W statistic (see Table 3) gives rise to accepting the null hypothesis of no serial correlation in the models. Furthermore, the regression specification (RESET) test suggested a case of omitted variables. This could - to a great extent - be attributed to the inconsistency and/or outright unavailability of data to directly measure or proxy most of Nigerian microeconomic and macroeconomic variables.

A close look at the models in Table 3, throws up basic facts: in models 1 and 3 capital (CAP) was significant with positive elasticities. From model 1, the indication is that 1 percent growth in capital formation will result in about 11.19 percent growth of the economy generally. On the other hand, model 2 showed that, about 12.52 percent growth in the economy would have resulted if sufficient capital was channelled into the manufacturing sector of the Nigerian economy, and this would have meant employment for the continuously growing Nigerian population, thereby making it productive. In the case of model 3 , capital indicated positive sign and was significant, however, with a very weak impact. The result reflected only 4.33 percent growth in agricultural productivity, showing its possible contribution to the growth of the national economy. This insignificant value still points to inadequate and sluggish process of capital formation. It makes economic sense, therefore, to argue that a persistent growth in population in an economy with sluggish pace in capital formation may not really result in meaningful economic progress.

Another variable is labour (proxied by the part of the total population termed 'active', i.e population between the ages 15 and 64). This variable is unique for the fact that it is the variable in the production function with direct bearing on the primary subject under study - population. From Table 3, models 1 and 3, have negative elasticities for labour (LAB) and were all insignificant. This sign negates the a priori expectation. This result underlines two basic facts: first, population growth could be a burden, no matter the size of the active part of that population, if human capital development is not a priority. This is clearly evident in the 
negative relationships the models portrayed in terms of this variable. This validates the argument that the size of the population is not as important as the quality. If there is persistent growth in population in any economy without conscious and commensurate development in human capital, that is focused and target-oriented, then such growth can only produce negative effects such as low per capita income and poverty. The second fact is related to the first. The insignificant few of the active population trained are not targeted, thus there are educated people but vital skills lacking, and as such the effects cannot be identifiable in the growth of the sectors and the growth of the general economy. The positive and significant elasticity, in the case of model 2, can be attributed to the boost labour in the manufacturing subsector receives due to in-training, short courses and on-the-job training individual firms undertake for efficiency. It also relates to internal and external economies of scale within the subsector.

In the case of human capital development (HCD), government expenditure on education and health was used as proxy. Though the signs were positive, the relation in model 1 was insignificant. The result shows that the level of human capital development in the country within the period under investigation can only bring about 1.41 percent improvements in the growth performance. This figure is of course very insignificant and as Awe and Ajayi (2010) and Isola and Alani (2002) found out, a dwindling growth in expenditure on human capital would only result in an increasing population with a crawling economy. However, the results for models 2 and 3 - manufacturing subsector and agricultural sector - were positive and significant. The elasticity for HCD was 11.01 percent for the manufacturing subsector and this indicates that improvements in human capital development would bring about 11.01 percent improvements in the manufacturing subsector output. This would mean improvement in the general wellbeing of the economy. On the other hand, though the relation in model 3 was positive and significant, the elasticity appeared very minute. This reflects the crude status that is still prevalent in the agricultural sector, but its significance underlines the fact that conscious practices that emphasise mechanised farming, associated with skilled work force and consistent training would make a very robust economy.

In the outcome of the results so far discussed, one outstanding fact is deduced: growth in population has a neutral role in boosting economic growth performance, except there is effective employment of the transmission mechanism, that is, the quality of the population in terms of human capital development must be taken seriously. This argument is in consonance with the second and third parts of the debate: (i) that growth in population is only useful if the population is of quality and (ii) that population growth in itself does not influence economic situation, but what is done with it and about it. It is therefore safe to say that there is evidence of positive impact that population growth exerts on the growth performance of the Nigerian economy, but this impact will be significant if the active population is of quality. Other variables in the models - which are final consumption expenditure, exchange rate and inflation employed as intervening variables in the models, behaved appropriately.

Consumption expenditure (CONEXP) had positive elasticities for models 1,2 , and 3 and they were significant. The elasticities were 35.04 percent, 71.30 percent and 9.68 percent respectively. The implication of this is that, ceteris paribus, consumption expenditure targeted at industrialisation-aiding infrastructural provisions, human capital development and export-oriented agriculture, will end up making the population structure of Nigeria a gainful and a growth-driving resource. Though the impact of inflation reflected by the regression line indicated a minute, but traceable negativity, (which is not strange in the literature), the negative relations it portrayed in models 1 and 3 , though positive and significant in the case of model 2 , should not be taken for granted in examining growth of the Nigerian economy. Exchange rate, though significant in the three models, showed negative sign in models 3. Two important facts ensue from this result: first, an economy with high population, low productivity, low export volume and high import volume, is very vulnerable in the face of unstable and unfavourable exchange rate. This is reflected in models 2 and 3 in table 3 . Model 3 had exchange rate coefficient -0.04 percent. This negative impact can be traceable to the inconsistency and instability associated with exchange rate in recent times in Nigeria. The second fact is that, no economy can boast of a stable beneficial exchange rate without a strong industrial sector (in fact the entire real sector), strong currency and strong presence in the international market place in terms of all-round exports.

\section{Conclusion and Policy Options}

This paper sought to assess the role of population growth in economic growth performance in Nigeria. The study employed time series data for the period $1981-2013$. Using Augmented Cobb-Douglass Production Function (gleaning from Solow Growth Model), and relying on error correction modelling framework, the econometric results established the fact that population growth has the potentials of fostering economic growth in Nigeria, but underlined the fact that this and other benefits would depend on, not only the chunk of the entire population that is active, but the quality of the active population. Based on this finding, the following policy options are suggested:

First, the negative signs associated with labour despite the robustness of it elasticities, and the insignificance of the statistical properties suggest that, though there is abundance of human resources, the quality of these resources which is critical for a productive economy is substandard. A need therefore arises for a conscious policy find-tuning that will enhance human capital development that will be focused and target-oriented. Education and training should be on carrier and development of skills in the manufacturing and agricultural sectors of the economy and should be intensified. Though statistically insignificant in model 1, the positive 
signs show that human capital development is an essential variable if population growth must be a blessing to the nation. This would mean that strategic policy that will enhance access to quality and affordable healthcare for the people must be in place. Efforts at developing a policy structure that drive a target-oriented education and training must be sustained.

Second, efforts at staging policies that will develop and sustain qualitative and viable human resource stock should be maintained in order to reap the full gains of population growth. As population in Nigeria grows, human capital development should be given the needed attention, as the level of human capital development in a country determines its pace of development.

\section{References}

[1] Adelakun, O. J. (2011) Human Capital Development and Economic Growth in Nigeria. European Journal of Business and Management, 3 (9).

[2] Adetiloye, K. A. and K. A. Adeyemo (2012): Domestic Investment, Capital Formation and Population Growth. Developing Country Studies. www.iiste.org, 2 (7).

[3] Adewole, A. O. (2012): "Effect of Population on Economic Development in Nigeria: A Quantitative Assessment". International Journal of Physical and Social Sciences, http://www.ijmras.us, 2 (5).

[4] Akpan, U. F. (2011), Cointegration, Causality and Wagner's Hypothesis: Time Series Evidence for Nigeria, 1970 - 2008. Journal of Economic Research (16), 59-84.

[5] Awe, A. A. and S. O. Ajayi (2010) The Nexus Between Human Capital Inestment and Economic Growth in Nigeria. Pakistan Journal of Social Sciences, 7 (1), 1-7.

[6] Becker G. S., Murphy K. M. and Tamura R. (1994). "Human Capital: A Theoretical and Empirical Analysis with Special Reference to Education" (3rd Edition). The University of Chicago Press. United States.

[7] Bloom, D. E. and Canning, D. (2000) "The Health and Wealth of Nations", Science. 287 (18), 1207-1209.

[8] Bloom, D. E., and Canning, D. (2003): "The health and poverty of nations: from theory to Practice". Journal of Human Development, 4(1), 47-71.

[9] Boserup, E. (1965). "The Conditions of Agricultural Growth". Chicago: Aldine

[10] Boserup, E. (1976). Environment, Population and Technology in Primitive Societies. Population and Development Review. 2 (1), 21-36.

[11] Boserup, E. (1981) Population and Technological Change, University of Chicago Press, Chicago.

[12] Bremner, J., López-Carr, D., Suter, L. and Davis, J. (2010) 'Population, poverty, environment, and climate dynamics in the developing world', Interdisciplinary Environmental Review. 11 2/3), 112-126.

[13] Brown, H. (1954): The Challenge of Man's Future: An Inquiry
Concerning the Condition of Man During the Years That Lie Ahead, Viking, New York.

[14] Campbell, O. and T. Agbiokoro (2014): "Human Capital and Economic Growth: A Three Stage Least Squares Approach". Journal of Economics and Sustainable Development, www.iiste.org, 5 (5).

[15] Cincotta, R. P. and Engelman, R. (1997) Economics and Rapid Change: The Influence of Population Growth. Population Action International, October.

[16] Cohen, J. E. (1995) "Population Growth and Earth's Human Carrying Capacity. American Association for the Advancement of Science, http//www.jstor.org, 269 (5222), 341 $-346$

[17] Dennis, E.F. (1962) Sources of Economic Growth in United States and the Alternatives Before US. Committee of Economic Development. New York, USA.

[18] Ekong, S. (1995) Economic Dislocation and Recovery in Lebanon. International Monetary Fund, Washington, DC., 64.

[19] Geda, A., N. Ndung'u and D. Zerfu (2012): Applied Time Series Econometrics: A Practical Guide for Macroeconomic Researchers with Focus on Africa, University of Nairobi Press, Nairobi, Kenya.

[20] Gemmell, N. (1999) Wagner's Law, Relative Prices and the Size of the Public Sector. Manchester School of Economics and Social Studies, 58, (4), 361-377.

[21] Grossman (1972) On the Concept of Health Capital and the Demand for Health. The Journal of Political Economy, 80 (2), 223-255. http://www.jstor.org/stable/1830580.

[22] Gujarati, D. N. (2003) Basic Econometrics, (3 $\left.{ }^{\text {rd }}\right)$, Mc GrawHill/Irwin, New York, USA.

[23] Harte, J. (2007) 'Human population as a dynamic factor in environmental degradation', Population and Environment, 28, (4-5), 223-236.

[24] Hern, W. M. (1993): "Has The Human Species Become A Cancer On The Planet? A Theoretical View of Population Growth As A Sign of Pathology". Current World Leaders, 36(6), 1089-1124.

[25] Herzer,D., F. Nowark-Lehmann and B. Silverstove (2004). "Export-Led Growth in Chile: Assessing the Role of Export Composition in Productivity Growth." www.igi.wiwi.unigoettingen.de

[26] IFAD (2012). Rural Poverty in Nigeria. HYPERLINK http://www.ruralpovertyportal.org

[27] IFAD (2013). Rural Poverty in Africa. http://www.ruralpovertyportal.org

[28] IMF (2014) World Population and Demographic Studies.

[29] Isola W. A. (2002): "The Economic Education Linkage: Evidence from Nigeria (1980-1999)" Lagos Journal of Educational Administration and Planning, Vol. 2, No. 1, pp. 16-32.

[30] Isola, W. A. and R. A. Alani (2012). "Human Capital Development and Economic Growth: Empirical Evidence from Nigeria." Asian economic and Financial Review. http//aessweb.com. 2 (7), 813-827. 
[31] Kanu, S. I. and B. A. Ozurumba (2014). Capital Formation and Economic Growth in Nigeria. Global Journal of HumanSocial Science: Economics, 14 (4).

[32] Karev, G. P. (2002): "Dynamics of Inhomogeneous Population and Global Demography Models". Oak Ridge Institute for Science and Education, National Institute of health, gkarev@hotmail.com.

[33] Manning, L. M. and D. Adriacanos (1993). "Dollar Movements and Inflation: A Cointegration Analysis." Applied Economics, 25, 1483-1488.

[34] Marquette, C. (1997): "Population and Environment Relationships in Developing Countries: A Selected Review of Approaches and Methods". Working Paper, Chr. Michelson Institute, Development Studies and Human Rights, Bergen, Norway, October, WP 1997; 15.

[35] MEA (2005) Ecosystems and Human Well-being: Synthesis, Millennium Ecosystem Assessment Synthesis Reports, Island Press, Washington DC.

[36] Nwosu, C., A. O. Dike and K. K. Okwara (2014): The Effects of Population Growth on Economic Growth in Nigeria. International Journal of Engineering and Science, 3 (11), 07 18

[37] Oser, J. and W. C. Blanchfield (1975), The History of Economic Thought, Harcourt Brace Jovanovich Publishers Inc. USA.

[38] Perron, P. (1997) Further Evidence on Breaking Trend Functions in Macroeconomic Variables, Journal of Econometrics, 80, (2), 335-385.

[39] Penck, A. (1925) Sitzungsberichte der Preußischen, Z. Geopolitik, (2). 330.

[40] Prettner, K and T. Trimborn (2012): "Demographic Change and $\mathrm{R} \& \mathrm{D}-$ Based Economic Growth: Reconciling Theory and Evidence". Centre for European Governance and Development Research, University of Gottingen, Germany.
[41] Schultz T. W (1961) "Investment in Human Capital." American Economic Review Vol. 51, No. 1, pp. 1-17.

[42] Schultz, T. P. (1992) "The Role of Education and Human Capital in Economic Development: An Empirical Assessment." Yale Economic Growth Center Discussion Papers Series. 670.

[43] Shultz T. P. (1961) "Education and Economic Growth" in: Social Forces Influencing American, Education. Ed. N.B. Henry Chicago. National Society for the Study of Education. University of Chicago Press.

[44] Solow R (1956). "A Contribution to the Theory of Economic Growth". The Quarterly Journal of Economics, Vol. 70(1), pp. 65-94.

[45] Thuku, G.K., G. Paul and O. Almadi (2013): "The Impact of Population Change on Economic Growth in Kenya" International Journal of Economics and Management Sciences, Vol. 3(6), pp 43-60.

[46] Uche, E., O. A. Ihugha and C. Nwosu (2013): "Causal Relationship between Nigeria Government Budget Allocation to the Education Sector and Economic Growth". Discourse Journal of Educational Research, www.resjournals.org/IJER, $1(8), 54-64$.

[47] Ukpong, I. G., I. D. Ekpebu and N. I. Ofem (2013): "Cointegration Inferences on Issues of Poverty and Population Growth in Nigeria". Journal of Development and Agricultural Economics, http//www.academicjournals.org/JDAE,. 5(7), 277 -283 .

[48] World Development Indicator (2014) Database for Development, World Bank.

[49] Westing, A. H. (1981): Environment Conservation, 8, 177.

[50] WHES (2012). World Hunger and Poverty Facts and Statistics. World Hunger Education Services. http://worldhunger.org. 